\title{
HUBUNGAN PENGETAHUAN SISWA/SISWI KELAS XI IPA TENTANG PENDIDIKAN SEKS DENGAN TINDAKAN SISWA/SISWI DI SMA N 1 DOLOKSANGGUL KECAMATAN DOLOKSANGGUL KABUPATEN HUMBANG HASUNDUTAN TAHUN 2016
}

\author{
Suriani Ginting \\ Jurusan Keperawatan Poltekkes Medan
}

\begin{abstract}
Abstrak
Banyak usia remaja yang telah melakukan hubungan seks di luar pernikahan. Salah satu penyebabnya adalah karena kurangnya pendidikan seks diberikan kepada remaja. Pendidikan seks sangat penting terutama untuk remaja. Dengan tujuan mengetahui tindakan siswa pengetahuan siswa dilihat dari pendidikan seks. Jenis penelitian yang digunakan dalam penelitian ini adalah deskriptif analitik dengan desain cross sectional. instrumen penelitian menggunakan kuesioner dan wawancara. Menggunakan analisis bivariat dengan uji chisquare. Jumlah sampel 100 responden, siswa kelas XI Ilmu di SMA N 1 Dolok Sanggul. Dari hasil penelitian sampel berjumlah 100 responden, dengan mayoritas memiliki perbuatan baik 71 responden (71\%), baik berpengetahuan 42 responden $(60,0 \%)$, jenis kelamin perempuan 55 responden $(78,6 \%)$, peran yang baik orang tua 43 responden $(55,8 \%)$, peran yang baik dari guru 50 responden $(63,3 \%)$, elektronik media informasi 53 responden $(50,0 \%)$, peran yang baik dari petugas kesehatan 36 responden $(62,1 \%)$, peran yang baik dari lingkungan (teman sebaya) 48 responden $(57,1 \%)$. Hasil analisis bivariat menunjukkan tidak ada hubungan antara jenis kelamin, peran guru, peran lingkungan (teman sebaya), tidak ada hubungan antara pengetahuan, peran orang tua, media dengan informasi tentang pendidikan seks dengan siswa tindakan di SMA N. 1 Dolok Sanggul. Diharapkan guru SMA N 1 Dolok Sanggul membina siswa menggunakan media informasi dengan benar, meningkatkan pengetahuan siswa tentang seks, kegiatan ekstrakurikuler begitu banyak untuk mengambil waktu hal bermanfaat. Orang tua tidak menganggap komunikasi tabu dengan anak-anak tentang seksualitas, lebih terbuka, sehingga anak-anak mendapatkan pendidikan yang benar atau informasi, sepervise semua kegiatan dan pergaulan di luar rumah.
\end{abstract}

Kata Kunci : Pengetahuan, Pendidikan Seks, Aksi Mahasiswa

\section{LATAR BELAKANG}

Kata remaja berasal dari bahasa latin "adolescentia" yang berat remaja yang mengalami kematangan fisik, emosi, mental dan social. Masa remaja merupakan masa peralihan dari masa pubertas menuju masa dewasa. Peralihan berarti terputus atau berubah dari apa yang pernah terjadi sebelumnya (Herri Zan,2011).

Batasan usia remaja menurut WHO (Word Health Organization) adalah mereka yang berusia 10-19 tahun. Sementara itu menurut The Health Resources and Services Administrasion Guedelines Amerika Serikat, rentang usia remaja adalah 11 sampai 21 tahun dan terbagi menjadi tiga tahap, yaitu remaja awal (11-14 tahun), remaja menengah (15-17 tahun), remaja akhir (18-21 tahun) (Kusmiran,2011).

Pergaulan yang sehat antara remaja laki-laki dan perempuan, serta kewaspadaan terhadap masalah remaja yang banyak ditemukan. Remaja memerlukan informasi tersebut agar selalu wapada dan berTindakan reproduksi sehat dalam bergaul dengan lawan jenisnya. Disamping itu remaja memerlukan pembekalan tentang kiat-kiat untuk mempertahankan diri secara fisik maupun psikis dan mental dalam menghadapi godaan, seperti ajakan untuk melakukan hubungan seksual dan penggunaan napza (Yani Widyastuti, 2009). Pendidikan seks seharusnya menyebabkan kaum muda berkembang menjadi orang yang sehat secara seksual, yang mampu membuat keputusan berdasarkan yang mereka peroleh, tentang kehidupan seks mereka saat ini dan dimasa yang akan datang (Anna Glasier,2010).

Terjadinya pergolakan emosional pada masa pubertas tidak terlepas dari berbagai macam pengaruh, seperti lingkungan tempat tinggal, keluarga, sekolah dan teman sebaya serta aktivitas yang dilakukannya.

Berdasarkan Sensus Penduduk dari Biro Pusat Statistik (BPS) pada tahun 2010, jumlah remaja di Indonesia usia 10-24 tahun sekitar 64 juta atau 27,6 persen dari jumlah penduduk sebanyak 237.6 juta jiwa. Jumlah penduduk Sumatera Utara sekitar 12.982.204 jiwa, dan 
terdapat jumlah remaja sekitar seperlima dari jumlah penduduk (374.661 jiwa). Sedangkan jumlah penduduk di Humbang Hasundutan 173.255 jiwa, dimana jumlah penduduk usia 10-19 tahun 24.462 jiwa yang terdiri dari remaja laki-laki 12.244 jiwa dan jumlah perempuan 12.218 jiwa (profil Humbang 2013). Jumlah penduduk Kecamatan Dolok Sanggul tahun 2013 adalah 43.997 jiwa, dimana jumlah penduduk remaja 7.876 jiwa dengan jumlah lakilaki 4.123 jiwa dan perempuan 3.753 jiwa (Profil Humbang Hasundutan 2013). Dengan jumlah remaja yang besar pada masa transisi kehidupan dari masa anak- anak menuju dewasa, maka remaja memiliki tugas perkembangan yang tidak mudah.

Berdasarkan Laporan Hasil Survei MCR-PKBI / Mitra Citra Remaja - Perkumpulan Keluarga Berencana Indonesia Jawa Barat, terdapat delapan faktor yang mempengaruhi terjadinya hubungan seksual pranikah atau seks bebas remaja. Berdasarkan jawaban yang masuk, faktor sulit mengendalikan dorongan seksual menduduki peringkat tertinggi $63,68 \%$, selanjutnya faktor kurang taat menjalankan agama 55,79\%, rangsangan seksual 52,63\%, sering nonton blue film 49,47\%, tidak ada bimbingan orang tua $9,47 \%$, pengaruh tren $24,74 \%$, tekanan dari lingkungan $18,42 \%$, dan masalah ekonomi $12,11 \%$.

Data BKKBN 2010 mencatat sebanyak 51 persen remaja di Jabodetabek telah melakukan hubungan layaknya suami istri. Selain Jabodetabek, data yang sama juga diperoleh di wilayah lain seperti Surabaya di mana remaja perempuan lajang yang kegadisannya sudah hilang mencapai 54 persen, di Medan 52 persen, Bandung 47 persen, dan Yogyakarta 37 persen.

seks seharusnya menyebabkan kaum muda berkembang menjadi orang yang sehat secara seksual, yang mampu membuat keputusan, berdasarkan yang mereka peroleh, tentang kehidupan seks mereka saat ini dan dimasa mendatang. Pendidikan tersebut seharusnya tidak saja memberikan fakta - fakta penting pada remaja, tetapi juga mengembangkan keterampilan mereka dalam menerapkan pengetahuan ini dalam konteks hidup sehari hari. Karena itu, pendidikan seks akan mencakup tidak saja belajar mengenai fakta fakta biologis yang "pasti", tetapi juga masalah masalah etik, kepercayaan, moralitas, dan nilai - nilai pribadi. Pendidikan seks memiliki banyak kesamaan dengan bidang bidang yang lain. Pendidikan ini sebaiknya sesuai dengan kebutuhan kaum muda, dan sesuai dengan budaya tempat mereka tinggal.(http://www.psychologymania.com/2013/02/pe ngertian-pendidikan-seks.html. diakses tanggal 22 Maret 2014 jam 10.26 WIB).)

Berdasarkan hasil data yang diperoleh oleh peneliti begitu banyak anak usia remaja yang sudah melakukan hubungan seks diluar nikah. Salah satu yang menjadi penyebabnya yaitu karena kurangnya pendidikan seks yang diberikan pada para remaja. Dan seharusnya pendidikan seks merupakan hal yang sangat penting yang perlu diberikan terkhususnya untuk para remaja, oleh karena itu peneliti merasa pendidikan seks masih sangat kurang terkhususnya dikalangan remaja.

\section{Perumusan Masalah}

Dari latar belakang diatas, maka penulis membuat rumusan masalah penelitian adalah: "Hubungan Pengetahuan Siswa/ siswi Kelas XI IPA Tentang Pendidikan Seks Dengan Tindakan Siswa/ siswi Di SMA N 1 Doloksanggul Kecamatan Doloksanggul Kabupaten Humbang Hasundutan Tahun 2015”.

\section{TUJUAN PENELITIAN}

\section{Tujuan Umum}

Untuk mengetahui : "Hubungan Pengetahuan Siswa/ siswi Kelas XI IPA Tentang Pendidikan Seks Dengan Tindakan Siswa/ siswi Di SMA N 1 Doloksanggul Kecamatan Doloksanggul Kabupaten Humbang Hasundutan Tahun 2015".

\section{Tujuan Khusus}

Tujuan khusus penelitian ini adalah:

a. Untuk mengetahui hubungan pengetahuan siswa/ siswi kelas XI IPA tentang pendidikan seks dengan Tindakan siswa/ siswi di SMA N 1 Doloksanggul berdasarkan jenis kelamin

b. Untuk mengetahui hubungan pengetahuan siswa/ siswi kelas XI IPA tentang pendidikan seks dengan Tindakan siswa/ siswi di SMA N 1 Doloksanggul berdasarkan peran orang tua.

c. Untuk mengetahui hubungan pengetahuan siswa/ siswi kelas XI IPA tentang pendidikan seks dengan Tindakan siswa/ siswi di SMA N 1 Doloksanggul berdasarkan peran guru.

d. Untuk mengetahui hubungan pengetahuan siswa/ siswi kelas XI IPA tentang pendidikan seks dengan Tindakan siswa/ siswi di SMA N 1 Doloksanggul berdasarkan media informasi.

e. Untuk mengetahui hubungan pengetahuan siswa/ siswi kelas XI IPA tentang pendidikan seks dengan Tindakan siswa/ siswi di SMA N 1 Doloksanggul berdasarkan tenaga kesehatan.

f. Untuk mengetahui hubungan pengetahuan siswa/ siswi kelas XI IPA tentang pendidikan seks dengan Tindakan siswa/ siswi di SMA N 1 Doloksanggul berdasarkan lingkungan (teman sebaya).

\section{MANFAAT PENELITIAN}

Hasil penelitian ini dapat dimanfaatkan sebagai sumber informasi dan bahan referensi untuk mengetahui tentang pendidikan seks serta manfaat pendidikan seks dalam membentuk tindakan dan Tindakan seorang remaja.

\section{Bagi Peneliti}

Sebagai bahan masukan untuk menambah wawasan dan memahami tentang pendidikan seks dalam upaya pembentukan tindakan dan tindakan seorang remaja. 


\section{METODE PENELITIAN}

\section{Jenis Penelitian}

Jenis penelitian ini merupakan penelitian yang berbentuk deskriptif analitik, yang terdiri atas variabel bebas dan terikat, dengan menggunakan desain cross sectional, dimana variabel bebas dan variabel terikat diukur dan dikumpulkan secara simultan (dalam waktu yang bersamaan) yang dilakukan dengan tujuan utamanya untuk mengetahui sejauh mana "Hubungan Pengetahuan Siswa/ Siswi Kelas XI IPA Tentang Pendidikan Seks Dengan Tindakan Siswa/ Siswi Di SMA N 1 Doloksanggul Kecamatan Doloksanggul Kabupaten Humbang Hasundutan Tahun 2015" (Soekidjo Notoatmojo, 2010).

\section{HASIL PENELITIAN DAN PEMBAHASAN}

\section{Hasil Penelitian}

Analisa Univariat

Analisa univariat dilakukan untuk menggambarkan penyajian data dari beberapa variabel dalam bentuk distribusi frekwensi, meliputi distribusi frekwensi responden berdasarkan, jenis kelamin, peran orangtua, peran guru, media informasi, peran tenaga kesehatan, peran lingkungan (teman sebaya) tentang tindakan siswa/ siswi di SMA N 1 Doloksanggul Kecamatan Doloksanggul Kabupaten Humbang Hasundutan Tahun 2015.

Tabel 1. Distribusi Frekwensi Responden Berdasarkan Pengetahuan, Jenis Kelamin, Peran Orang Tua, Peran Guru, Media Informasi, Perang Tenaga Kesehatan, Peran Lingkungan (Teman Sebaya), Tindakan Siswa/Siswi Kelas XI di SMA N 1 Doloksanggul Kecamatan Doloksanggul Kabupaten Humbang Hasundutan Tahun 2015

\begin{tabular}{|c|c|c|c|}
\hline No & Variabel & Jumlah & $\begin{array}{c}\text { Persentase } \\
(\%)\end{array}$ \\
\hline \multirow[t]{5}{*}{1.} & Pengetahuan & & \\
\hline & Baik & 71 & 71 \\
\hline & Cukup & 22 & 22 \\
\hline & Kurang & 7 & 7 \\
\hline & Total & 100 & 100 \\
\hline \multirow[t]{4}{*}{2.} & Jenis Kelamin & & \\
\hline & Laki-Laki & 30 & 30 \\
\hline & Perempuan & 70 & 70 \\
\hline & Total & 100 & 100 \\
\hline \multirow[t]{5}{*}{3.} & Peran Orangtua & & \\
\hline & Baik & 77 & 77 \\
\hline & Cukup & 17 & 17 \\
\hline & Kurang & 6 & 6 \\
\hline & Total & 100 & 100 \\
\hline \multirow[t]{5}{*}{4.} & Peran Guru & & \\
\hline & Baik & 79 & 79 \\
\hline & Cukup & 15 & 15 \\
\hline & Kurang & 6 & 6 \\
\hline & Total & 100 & 100 \\
\hline \multirow[t]{4}{*}{5.} & Media Informasi & & \\
\hline & Media Cetak & 7 & 7 \\
\hline & Media Elektronik & 93 & 93 \\
\hline & Total & 100 & 100 \\
\hline \multirow[t]{5}{*}{6.} & Peran Tenaga Kesehatan & & \\
\hline & Baik & 58 & 58 \\
\hline & Cukup & 22 & 22 \\
\hline & Kurang & 20 & 20 \\
\hline & Total & 100 & 100 \\
\hline \multirow[t]{5}{*}{7.} & Peran Lingkungan (Teman Sebaya) & & \\
\hline & Baik & 84 & 84 \\
\hline & Cukup & 16 & 16 \\
\hline & Kurang & 0 & 0 \\
\hline & Total & 100 & 100 \\
\hline \multirow[t]{5}{*}{8.} & Tindakan Siswa/ Siswi & & \\
\hline & Baik & 58 & 58 \\
\hline & Cukup & 16 & 16 \\
\hline & Kurang & 26 & 26 \\
\hline & Total & 100 & 100 \\
\hline
\end{tabular}


Pada Tabel 1 dapat dilihat bahwa pengetahuan responden yaitu mayoritas berpengetahuan baik yaitu 70 responden $(70 \%)$ dan minoritas berpengetahuan kurang yaitu 7 responden $(7 \%)$.

Berdasarkan jenis kelamin responden mayoritas berjenis kelamin perempuan yaitu 70 responden (70\%) dan minoritas laki - laki yaitu 30 responden (30\%).

Berdasarkan peran orangtua mayoritas baik sebanyak 77 responden $(77 \%)$ dan minoritas yaitu kurang yaitu sebanyak 6 responden $(6 \%)$.

Berdasarkan peran guru mayoritas baik yaitu sebanyak 79 responden (79\%) dan minoritas kurang sebanyak 6 responden $(6 \%)$.

Berdasarkan media informasi mayoritas dari media elektronik sebanyak 93 responden (93\%) dan minoritas media cetak sebanyak 7 responden (7\%).

Berdasarkan peran tenaga kesehatan mayoritas baik yaitu sebanyak 58 responden $(58 \%)$ dan minoritas kurang sebanyak 20 responden (20\%).

Berdasarkan peran lingkungan (teman sebaya) mayoritas baik sebanyak 84 responden (84\%) dan minoritas kurang sebanyak 0 responde $(0 \%)$.

Berdasarkan tindakan mayoritas baik sebanyak 79 responden dan minoritas kurang sebanyak 0 responden $(0 \%)$.

\section{Analisa Bivariat}

Adalah setelah diketahui variabel, maka dilakukan analisa lebih lanjut berupa analisa bivariat, data yang didapat dari kedua variabel merupakan data kategori, maka uji statistik menggunakan uji chi-square yang bertujuan untuk mengetahui hubungan pengetahuan siswa/ Siswi tentang pendidikan seks dengan tindakan siswa/ Siswi.

Tabel 2 Distribusi Frekwensi Pengetahuan Responden tentang Pendidikan Seks dengan Tindakan Siswa/Siswi Kelas XI Berdasarkan Pengetahuan di SMA N 1 Doloksanggul Kecamatan Doloksanggul Kabupaten Humbang Hasundutan Tahun 2015

\begin{tabular}{|c|c|c|c|c|c|c|c|c|c|c|c|}
\hline \multirow{3}{*}{ No } & \multirow{3}{*}{$\begin{array}{c}\text { Pengeta } \\
\text { huan }\end{array}$} & \multicolumn{10}{|c|}{ Tindakan Siswa/ Siswi } \\
\hline & & \multicolumn{2}{|c|}{ Baik } & \multicolumn{2}{|c|}{ Cukup } & \multicolumn{2}{|c|}{ Kurang } & \multicolumn{2}{|c|}{ Total } & \multirow[b]{2}{*}{ df } & \multirow[b]{2}{*}{$\mathbf{x}^{2}$} \\
\hline & & $\mathbf{n}$ & $\%$ & $\mathbf{N}$ & $\%$ & $\mathbf{N}$ & $\%$ & n & $\%$ & & \\
\hline 1. & Baik & 42 & 60,0 & 9 & 11,4 & 20 & 28,6 & 71 & 100 & \multirow{3}{*}{4} & \multirow{3}{*}{2,976} \\
\hline 2. & Cukup & 12 & 54,5 & 6 & 27,3 & 4 & 18,2 & 22 & 100 & & \\
\hline 3. & Kurang & 4 & 57,1 & 1 & 14,3 & 2 & 28,6 & 7 & 100 & & \\
\hline
\end{tabular}

Pada tabel 2 dapat dilihat bahwa dari 70 responden yang berpengetahuan baik mayoritas 42 responden $(60,0 \%)$ yang bertindakan baik dan minoritas 9 responden $(11,4 \%)$ yang bertindakan cukup. Dari 22 responden yang berpengetahuan cukup mayoritas 12 responden $(54,5 \%)$ yang bertindakan baik dan minoritas 4 responden $(18,2 \%)$ yang bertindakan kurang. Dan dari 7 responden yang berpengetahuan kurang mayoritas 4 responden $(57,1 \%)$ bertindakan baik dan minoritas 1 responden $(14,3 \%)$ bertindakan cukup.

Dengan uji chi-square dalam tingkat kepercayaan $95 \%(\alpha: 0,05 \%)$ dan $\mathrm{df}=4$ diperoleh $\mathrm{x}^{2}$ hitung $(2,976)<\mathrm{x}^{2}$ tabel $(9,488)$, maka Ha ditolak, Ho diterima sehingga tidak ada hubungan antara pengetahuan dengan tindakan siswa/ Siswi di SMA N 1 Doloksanggul Kecamatan Doloksanggul Kabupaten Humbang Hasundutan Tahun 2015.

Tabel 3 Distribusi Frekwensi Pengetahuan Responden Tentang Pendidikan Seks dengan Tindakan Siswa/Siswi Kelas XI Berdasarkan Jenis Kelamin di SMA N 1 Doloksanggul Kecamatan Doloksanggul Kabupaten Humbang Hasundutan Tahun 2015

\begin{tabular}{|c|c|c|c|c|c|c|c|c|c|c|c|}
\hline \multirow{3}{*}{ No } & \multirow{3}{*}{$\begin{array}{c}\text { Jenis } \\
\text { Kelamin }\end{array}$} & \multicolumn{10}{|c|}{ Tindakan Siswa/ Siswi } \\
\hline & & \multicolumn{2}{|c|}{ Baik } & \multicolumn{2}{|c|}{ Cukup } & \multicolumn{2}{|c|}{ Kurang } & \multicolumn{2}{|c|}{ Total } & \multirow[b]{2}{*}{ df } & \multirow[b]{2}{*}{$\mathbf{x}^{2}$} \\
\hline & & $\mathbf{n}$ & $\%$ & $\mathbf{N}$ & $\%$ & $\mathbf{N}$ & $\%$ & $\mathbf{n}$ & $\%$ & & \\
\hline 1. & Laki-Laki & 3 & 10,0 & 1 & 3,3 & 26 & 86,7 & 30 & 100 & & \\
\hline 2. & Perempuan & 55 & 78,6 & 15 & 21,4 & 0 & 0 & 70 & 100 & & 81,989 \\
\hline
\end{tabular}

Pada tabel 3 dapat dilihat bahwa dari 30 responden laki - laki mayoritas yang mempunyai tindakan kurang sebanyak 26 responden $(86,7 \%)$ dan minoritas mempunyai tindakan cukup sebanyak 1 responden (3,3\%). Dari 70 responden perempuan, mayoritas 55 responden $(78,6 \%)$ bertindakan baik dan minoritas 0 responden $(0 \%)$ bertindakan kurang.

Dengan uji chi-square dalam tingkat kepercayaan $95 \%(\alpha: 0,05 \%)$ dan $\mathrm{df}=2$ diperoleh $\mathrm{x}^{2}$ hitung $(81,989)>\mathrm{x}^{2}$ tabel $(5,991)$, maka Ha diterima, Ho ditolak sehingga ada hubungan antara jenis kelamin dengan tindakan siswa/ Siswi di SMA N 1 Doloksanggul Kecamatan Doloksanggul Kabupaten Humbang Hasundutan Tahun 2015.

Tabel 4 Distribusi Frekwensi Pengetahuan Responde Tentang Pendidikan Seks dengan Tindakan Siswa/Siswi Kelas XI Berdasarkan Peran Orang Tua di SMA N 1 Doloksanggul Kecamatan Doloksanggul Kabupaten Humbang Hasundutan Tahun 2015

\begin{tabular}{|c|c|c|c|c|c|c|c|c|c|c|c|}
\hline \multirow{3}{*}{ No } & \multirow{3}{*}{$\begin{array}{c}\text { Peran } \\
\text { Orangtua }\end{array}$} & \multicolumn{10}{|c|}{ Tindakan Siswa/ Siswi } \\
\hline & & \multicolumn{2}{|c|}{ Baik } & \multicolumn{2}{|c|}{ Cukup } & \multicolumn{2}{|c|}{ Kurang } & \multicolumn{2}{|c|}{ Total } & \multirow{2}{*}{ df } & \multirow{2}{*}{$x^{2}$} \\
\hline & & $\mathbf{N}$ & $\%$ & $\mathbf{N}$ & $\%$ & $\mathbf{N}$ & $\%$ & $\mathbf{n}$ & $\%$ & & \\
\hline 1. & Baik & 43 & 55,8 & 14 & 18,2 & 20 & 26,0 & 77 & 100 & & \\
\hline 2. & Cukup & 12 & 70,6 & 1 & 5,9 & 4 & 23,5 & 17 & 100 & 4 & 2,075 \\
\hline 3. & Kurang & 3 & 50,0 & 1 & 16,7 & 2 & 33,3 & 6 & 100 & & \\
\hline
\end{tabular}

Pada tabel 4 dapat dilihat bahwa dari 77 responden yang peran orangtua baik mayoritas 43 responden $(55,8 \%)$ bertindakan baik dan minoritas 14 responden $(18,2 \%)$ bertindakan cukup. Dari 17 responden yang peran orangtua cukup, mayoritas 12 responden $(70,6 \%)$ bertindakan baik dan minoritas 1 responden $(5,9 \%)$ bertindakan cukup.

Dengan uji chi-square dalam tingkat kepercayaan $95 \%(\alpha: 0,05 \%)$ dan $\mathrm{df}=4$ diperoleh $\mathrm{x}^{2}$ hitung $(2,075)>\mathrm{x}^{2}$ tabel $(9,488)$ maka Ho diterima, Ha ditolak sehingga tidak ada hubungan antara peran orangtua dengan tindakan siswa/ Siswi di SMA N 1 Doloksanggul Kecamatan Doloksanggul Kabupaten Humbang Hasundutan Tahun 2015. 
Tabel 5 Distribusi Frekwensi Pengetahuan Responden Tentang Pendidikan Seks dengan Tindakan Siswa/Siswi Kelas XI Berdasarkan Peran Guru di SMA N 1 Doloksanggul Kecamatan Doloksanggul Kabupaten Humbang Hasundutan Tahun 2015

\begin{tabular}{|c|c|c|c|c|c|c|c|c|c|c|c|}
\hline \multirow{3}{*}{ No } & \multirow{3}{*}{$\begin{array}{c}\text { Peran } \\
\text { Guru }\end{array}$} & \multicolumn{10}{|c|}{ Tindakan Siswa/ Siswi } \\
\hline & & \multicolumn{2}{|c|}{ Baik } & \multicolumn{2}{|c|}{ Cukup } & \multicolumn{2}{|c|}{ Kurang } & \multicolumn{2}{|c|}{ Total } & \multirow[b]{2}{*}{ df } & \\
\hline & & $\mathbf{N}$ & $\%$ & $\mathbf{N}$ & $\%$ & $\mathbf{N}$ & $\%$ & $\mathbf{n}$ & $\%$ & & \\
\hline 1. & Baik & 50 & 63,3 & 11 & 13,9 & 18 & 22,8 & 79 & 100 & & \\
\hline 2. & Cukup & 4 & 26,7 & 3 & 20,0 & 8 & 53,3 & 15 & 100 & 4 & 10,672 \\
\hline 3. & Kurang & 4 & 66,7 & 2 & 33,3 & 0 & 0 & 6 & 100 & & \\
\hline
\end{tabular}

Pada table 5 dapat dilihat bahwa dari 79 responden yang peran orang guru baik mayoritas 50 responden $(63,3 \%)$ bertindakan baik dan minoritas 11 responden $(13,9 \%)$ bertindakan cukup. Dari 15 responden yang peran guru cukup, mayoritas 8 responden $(53,3 \%)$ bertindakan kurang dan minoritas 3 responden $(20,0 \%)$ bertindakan cukup. Dari 6 responden yang peran guru kurang mayoritas 4 responden $(66,7 \%)$ bertindakan baik dan minoritas 0 responden $(0 \%)$ bertindakan kurang.

Dengan uji chi-square dalam tingkat kepercayaan $95 \%(\alpha: 0,05)$ dan $\mathrm{df}=4$ diperoleh $\mathrm{x}^{2}$ hitung $(10,672)>\mathrm{x}^{2}$ tabel $(9,488)$ maka Ha diterima, Ho ditolak sehingga ada hubungan peran guru dengan tindakan siswa/ Siswi di SMA N 1 Doloksanggul Kecamatan Doloksanggul Kabupaten Humbang Hasundutan Tahun 2015.

Tabel 6. Distribusi Frekwensi Pengetahuan Responden Tentang Pendidikan Seks dengan Tindakan Siswa/Siswi Kelas XI Berdasarkan Media Informasi di SMA N 1 Doloksanggul Kecamatan Doloksanggul Kabupaten Humbang Hasundutan Tahun 2015

\begin{tabular}{|c|c|c|c|c|c|c|c|c|c|c|c|}
\hline \multirow{3}{*}{ No } & \multirow{3}{*}{$\begin{array}{c}\text { Media } \\
\text { Informasi }\end{array}$} & \multicolumn{10}{|c|}{ Tindakan Siswa/Siswi } \\
\hline & & \multicolumn{2}{|c|}{ Baik } & \multicolumn{2}{|c|}{ Cukup } & \multicolumn{2}{|c|}{ Kurang } & \multicolumn{2}{|c|}{ Total } & \multirow[b]{2}{*}{ df } & \multirow[b]{2}{*}{$x^{2}$} \\
\hline & & $\mathbf{n}$ & $\%$ & $\mathbf{N}$ & $\%$ & $\mathbf{N}$ & $\%$ & $\mathbf{n}$ & $\%$ & & \\
\hline 1. & $\begin{array}{l}\text { Media } \\
\text { Cetak }\end{array}$ & 5 & 71,4 & 1 & 14,3 & 1 & 14,3 & 7 & 100 & \multirow{2}{*}{2} & \multirow{2}{*}{0,645} \\
\hline 2. & $\begin{array}{l}\text { Media } \\
\text { Elektronik }\end{array}$ & 53 & 57,0 & 15 & 16,1 & 25 & 26,9 & 93 & 100 & & \\
\hline
\end{tabular}

Pada tabel 6 dapat dilihat bahwa dari 7 responden yang mendapat informasi dari media cetak mayoritas 5 responden $(71,4 \%)$ bertindakan baik, dan minoritas 1 responden $(14,3 \%)$ bertindakan cukup dan 1 responden $(14,3 \%)$ bertindakan kurang. Dari 93 responden yang mendapat informasi dari media elektronik 53 responden $(57,0 \%)$ bertindakan baik dan minoritas 15 responden $(16,1 \%)$ bertindakan cukup.

Dengan uji chi-square dalam tingkat kepercayaan $95 \%(\alpha: 0,05 \%)$ dan $\mathrm{df}=2$ diperoleh $\mathrm{x}^{2}$ hitung $(0,645)<\mathrm{x}^{2}$ tabel $(5,991)$, maka Ho diterima, Ha ditolak sehingga tidak ada hubungan antara media informasi dengan tindakan siswa/ Siswi di SMA N 1 Doloksanggul Kecamatan Doloksanggul Kabupaten Humbang Hasundutan Tahun 2015.
Tabel 7 Distribusi Frekwensi Pengetahuan Responden tentang Pendidikan Seks dengan Tindakan Siswa/Siswi Kelas XI Berdasarkan Peran Tenaga Kesehatan di SMA N 1 Doloksanggul Kecamatan Doloksanggul Kabupaten Humbang Hasundutan Tahun 2015

\begin{tabular}{|c|c|c|c|c|c|c|c|c|c|c|c|}
\hline \multirow{3}{*}{ No } & \multirow{3}{*}{$\begin{array}{c}\text { Peran } \\
\text { Tenaga } \\
\text { Kesehatan }\end{array}$} & \multicolumn{10}{|c|}{ Tindakan Siswa/Siswi } \\
\hline & & \multicolumn{2}{|c|}{ Baik } & \multicolumn{2}{|c|}{ Cukup } & \multicolumn{2}{|c|}{ Kurang } & \multicolumn{2}{|c|}{ Total } & \multirow[b]{2}{*}{ df } & \multirow[b]{2}{*}{$x^{2}$} \\
\hline & & $\mathbf{n}$ & $\%$ & $\mathbf{N}$ & $\%$ & $\mathbf{n}$ & $\%$ & $\mathbf{n}$ & $\%$ & & \\
\hline 1. & Baik & 36 & 62,1 & 8 & 13,8 & 14 & 24,1 & 58 & 100 & & \\
\hline 2. & Cukup & 8 & 36,4 & 4 & 18,2 & 10 & 45,5 & 22 & 100 & 4 & 8,129 \\
\hline 3. & Kurang & 14 & 70,0 & 4 & 20,0 & 2 & 10,0 & 20 & 100 & & \\
\hline
\end{tabular}

Dari tabel 7 dapat dilihat bahwa dari 58 responden yang mendapat peran tenaga kesehatan baik mayoritas 36 responden $(62,1 \%)$ bertindakan baik dan minoritas 8 responden $(13,8 \%)$ bertindakan cukup. Dari 22 responden yang mendapat peran tenaga kesehatan cukup mayoritas 10 responden $(45,5 \%)$ bertindakan kurang dan minoritas 4 responden $(18,2 \%)$ bertindakan cukup. Dari 20 responden yang mendapat peran dari tenaga kesehatan kurang mayoritas 14 responden $(70,0 \%)$ bertindakan baik dan minoritas 2 responden $(10,0 \%)$ bertindakan cukup.

Dengan uji chi-square dalam tingkat kepercayaan $95 \%(\alpha: 0,05 \%)$ dan $\mathrm{df}=4$ diperoleh $\mathrm{x}^{2}$ hitung $(8,129)<\mathrm{x}^{2}$ tabel $(9,488)$, maka Ho diterima dan Ha ditolak, sehingga tidak ada hubungan antara peran tenaga kesehatan dengan tindakan siswa/ Siswi di SMA N 1 Doloksanggul Kecamatan Doloksanggul Kabupaten Humbang Hasundutan Tahun 2015.

Tabel 8 Distribusi Frekwensi Pengetahuan Responden Tentang Pendidikan Seks dengan Tindakan Siswa/Siswi Kelas XI Berdasarkan Peran Lingkungan (Teman Sebaya) di SMA N 1 Doloksanggul Kecamatan Doloksanggul Kabupaten Humbang Hasundutan Tahun 2015

\begin{tabular}{|c|c|c|c|c|c|c|c|c|c|c|c|}
\hline \multirow{3}{*}{\multicolumn{2}{|c|}{$\begin{array}{cc}\text { Peran } \\
\text { No } & \begin{array}{c}\text { Lingkungan } \\
\text { (Teman } \\
\text { Sebaya) }\end{array} \\
\end{array}$}} & \multicolumn{10}{|c|}{ Tindakan Siswa/Siswi } \\
\hline & & \multicolumn{2}{|c|}{ Baik } & \multicolumn{2}{|c|}{ Cukup } & \multicolumn{2}{|c|}{ Kurang } & \multicolumn{2}{|c|}{ Total } & \multirow[b]{2}{*}{ df } & \multirow[b]{2}{*}{$\mathrm{x}^{2}$} \\
\hline & & $\mathbf{n}$ & $\%$ & $\mathbf{N}$ & $\%$ & $\mathbf{N}$ & $\%$ & $\mathbf{n}$ & $\%$ & & \\
\hline 1. & Baik & 48 & 57,1 & 14 & 16,7 & 22 & 26,2 & 60 & 100 & & \\
\hline 2. & Cukup & 10 & 62,5 & 2 & 12,5 & 4 & 25,0 & 15 & 100 & 4 & 186,739 \\
\hline 3. & Kurang & 0 & 0 & 0 & 0 & 25 & 100 & 25 & 100 & & \\
\hline
\end{tabular}

Dari tabel 8 dapat dilihat bahwa dari 60 responden yang mendapat peran dari lingkungan (teman sebaya) baik mayoritas 48 responden $(57,1 \%)$ bertindakan baik dan minoritas 14 responden $(16,7 \%)$ bertindakan cukup. Dari 15 responden yang mendapat peran dari lingkungan (teman sebaya) cukup mayoritas 10 responden $(62,5 \%)$ bertindakan baik dan minoritas 2 responden $(12,5 \%)$ bertindakan cukup. Dan dari 25 responden yang mendapat peran lingkungan (teman sebaya) mayoritas 25 reponden $(100 \%)$.

Dengan uji chi-square dalam tingkat kepercayaan $95 \%(\alpha: 0,05 \%)$ dan $\mathrm{df}=4$ diperoleh $\mathrm{x}^{2}$ hitung $(186,739)>$ $\mathrm{x}^{2}$ tabel $(9,488)$, maka Ho ditolak dan Ha diterima, sehingga ada hubungan antara peran lingkungan (teman sebaya) dengan tindakan siswa/ Siswi di SMA N 1 
Doloksanggul Kecamatan Doloksanggul Kabupaten Humbang Hasundutan Tahun 2015.

\section{PEMBAHASAN}

Hubungan Pengetahuan Siswa/Siswi Tentang Pendidikan Seks Berdasarkan Jenis Kelamin dengan Tindakan Siswa/Siswi di SMA N 1 Doloksanggul Kecamatan Doloksanggul Kabupaten Humbang Hasundutan Tahun 2015.

Berdasarkan uji chi-square, tidak ada hubungan antara pengetahuan responden tentang pendidikan seks dengan tindakan siswa/ Siswi di SMA N 1 Doloksanggul Kecamatan Doloksanggul Kabupaten Humbang Hasundutan Tahun 2015.

Pengetahuan (knowledge) adalah hasil tahu dari manusia, yang sekedar menjawab pertanyaan "what", pengetahuan hanya dapat menjawab pertanyaan apa sesuatu itu.

Menurut asumsi peneliti hasil penelitian menunjukkan dari 77 siswa/ Siswi berpengetahuan baik, ditemukan 42 responden $(60 \%)$ bertindakan baik. Namun dalam penelitian ini ditemukan bahwa pengetahuan tidak berhubungan dengan tindakan siswa/ Siswi dikarenakan siswa/ Siswi tersebut tidak mengaplikasikan pengetahuan yang telah mereka miliki terhadap tindakan mereka sehingga dalam penelitian ini tidak ditemukan adanya hubungan antara pengetahuan dengan tindakan yang dilakukan oleh siswa/ Siswi tersebut.

\section{Hubungan Pengetahuan Siswa/Siswi Tentang Pendidikan Seks Berdasarkan Jenis Kelamin dengan Tindakan Siswa/Siswi di SMA N 1 Doloksanggul Kecamatan Doloksanggul Kabupaten Humbang Hasundutan Tahun 2015.}

Berdasarkan uji chi-square, ada hubungan antara jenis kelamin tentang pendidikan seks dengan tindakan siswa/ Siswi di SMA N 1 Doloksanggul Kecamatan Doloksanggul Kabupaten Humbang Hasundutan Tahun 2015.

Menurut asumsi hasil pengolahan data variabel jenis kelamin ditemukan dari 100 responden yang diteliti terdapat 30 reponden laki-laki dimana 26 responden $(86,7 \%)$ bertindakan kurang. Dan terdapat 70 responden perempuan dimana 55 responden $(78,6 \%)$ memiliki tindakan yang baik. Menurut asumsi peneliti hal ini terjadi karena laki-laki biasanya lebih mudah terpengaruh oleh lingkungan sekitar dibandingkan dengan perempuan sehingga banyak laki-laki yang memiliki tindakan/ tindakan yang kurang dikarenakan tidak dapat menahan diri. Dimana pada saat peneliti melakukan penelitian ketika peneliti mengatakan kata seks terlihat para lelaki lebih antusias dan lelaki cenderung mengaitkan kata seks kearah yang negatif.
Hubungan Pengetahuan Siswa/Siswi Tentang Pendidikan Seks Berdasarkan Peran Orangtua dengan Tindakan Siswa/Siswi di SMA N 1 Doloksanggul Kecamatan Doloksanggul Kabupaten Humbang Hasundutan Tahun 2015.

Berdasarkan uji chi-square, tidak ada hubungan antara peran orangtua tentang pendidikan seks dengan tindakan siswa/ Siswi di SMA N 1 Doloksanggul Kecamatan Doloksanggul Kabupaten Humbang Hasundutan Tahun 2015.

Menurut asumsi peneliti dari hasil pengolahan data variabel ditemukan dari 77 siswa/ Siswi yang mendapat peran atau didikan orangtua yang baik 43 siswa/ Siswi $(55,8 \%)$ bertindakan baik, yang mana menurut peneliti ini berkaitan dengan teori yang mengatakan pada masa remaja sering terjadi adanya kesenjangan dan konflik antara remaja dengan orangtuanya. Pada saat ini ikatan emosional menjadi berkurang dan remaja sangat membutuhkan kebebasan emosional dari orangtuanya, misalnya dalam hal memilih teman ataupun melakukan aktivitas (Koes, Irianto, 2013) hal ini mengakibatkan pada saat orangtua mendidik anaknya, sianak cenderung bersikap acuh dan tak memperhatikan yang mengakibatkan anak justru bertindakan pada hal-hal yang telah dilarang orang tua. Hal ini dapat dilihat dari wawancara yang peneliti lakukan dimana kebanyakan responden mengatakan tidak pernah berdiskusi dengan orangtuanya apabila ia memiliki pacar. Sehingga walaupun didikan orang tua baik terkadang seorang remaja malah berperilaku/ bertindakan kurang.

Hubungan Pengetahuan Siswa/Siswi Tentang Pendidikan Seks Berdasarkan Peran Guru dengan Tindakan Siswa/Siswi di SMA N 1 Doloksanggul Kecamatan Doloksanggul Kabupaten Humbang Hasundutan Tahun 2015.

Menurut uji chi-square ada hubungan antara peran guru tentang pendidikan seks dengan tindakan siswa/ Siswi di SMA N 1 Doloksanggul Kecamatan Doloksanggul Kabupaten Humbang Hasundutan Tahun 2015.

Menurut asumsi peneliti dalam penelitian ini peran guru memiliki hubungan terhadap pembentukan tindakan siswa/ Siswi dikarenakan anak remaja yang sudah duduk dibangku SMP atau SMA umumnya menhabiskan waktu sekitar 7 jam sehari di sekolahnya. Ini berarti bahwa hampir sepertiga dari waktunya setiap hari dilewatkan remaja di sekolah.

Menurut asumsi peneliti dari hasil pengolahan data variabel peran guru berhubungan dengan pembentukan tindakan siswa/ Siswi dengan hasil penelitian yang didapat dari 79 responden yang mendapat peran guru yang baik dimana 50 responden $(63,3 \%)$ bertindakan baik.

\footnotetext{
Hubungan Pengetahuan Siswa/Siswi Tentang Pendidikan Seks Berdasarkan Media Informasi dengan Tindakan Siswa/Siswi di SMA $\quad$ N 1 Doloksanggul Kecamatan Doloksanggul Kabupaten Humbang Hasundutan Tahun 2015.

Berdasarkan uji chi-square, tidak ada hubungan antara media informasi tentang pendidikan seks dengan tindakan siswa/ Siswi di SMA N 1 Doloksanggul
} 
Kecamatan Doloksanggul Kabupaten Humbang Hasundutan Tahun 2015.

Kenneavy et.al. (2006) menyebutkan bahwa pada usia remaja, pencarian informasi merupakan salah satu hal yang penting, terutama informasi mengenai seks dan aturan orang dewasa. Media elektronik merupakan sumber pencarian yang paling banyak digunakan oleh remaja karena media ini sangat mudah diakses dan pesan yang disampaikan oleh media elektronik juga sangat efektif dan atraktif. Selain memberikan informasi mengenai seks secara bebas, media elektronik juga memberikan contoh tindakan kekerasan bagi remaja (Listora, 2013).

Menurut asumsi peneliti dalam penelitian ini media memegang peran yang sangat penting dalam menyebarkan informasi, kemajuan teknologi membawa dampak besar pada kehidupan remaja. Pada saat ini media elektronik bukan merupakan barang mewah lagi terbukti di SMA N 1 Doloksanggul hampir semua siswa/ Siswi memiliki hand phone sehingga mudah remaja mengakses informasi mengenai seks. Selain itu, banyaknya VCD dan DVD porno yang dijual murah secara bebas menyebabkan remaja dapat menonton VCD /DVD. Begitu juga tayangan sinetron di televisi yang banyak menanyangkan cara pacaran anak sekolah sehingga ketika mereka melihat tindakan yang di tampilkan di televisi dan akhirnya mengadosi tindakan gaya pacaran yang juga mempengaruhi cara mereka berpacaran sehingga berpengaruh terhadap pembentukan tindakan siswa/ Siswi tersebut.

Dari hasil pengolahan data variabel media informasi tidak berhubungan dengan pembentukan tindakan siswa/ Siswi dengan hasil penelitian yang didapat dari 100 responden yang diteliti terdapat 93 responden yang menggunakan media elektronik untuk mendapatkan informasi mengenai seks dan 53 responden $(57 \%)$ berperilaku/ bertindakan baik. Media informasi memang sering dikaitkan dengan tindakan seorang remaja namun hal ini kembali kepada sifat seorang remaja tersebut apakah dia termasuk orang yang mudah terpengaruh atau tidak.

Hubungan Pengetahuan Siswa/Siswi Tentang
Pendidikan Seks Berdasarkan peran tenaga kesehatan
dengan Tindakan Siswa/Siswi di SMA N 1
Doloksanggul Kecamatan Doloksanggul Kabupaten
Humbang Hasundutan Tahun 2015.
Berdasarkan uji chi-square, tidak ada hubungan antara peran tenaga kesehatan tentang pendidikan seks dengan tindakan siswa/ Siswi di SMA N 1 Doloksanggul Tahun 2015.

Menurut asumsi peneliti dalam penelitian ini hasil penelitian tidak sesuai dengan teori bahwa peran tenaga kesehatan memiliki hubungan dalam pembentukan tindakan remaja yaitu dari 100 responden diteliti 58 reponden yang mendapatkan peran tenaga kesehatan baik dimana 36 responden $(62,1 \%)$ bertindakan baik dan 14 responden $(24,1 \%)$ berperilaku/ bertindakan kurang. Dan terdapat 22 responden yang mendapat peran dari tenaga kesehatan cukup dimana mayoritas 10 responden $(45,5 \%)$ bertindakan/ berperilaku kurang. Dan terdapat pula 20 responden yang mendapatkan peran tenaga kesehatan yang kurang dimana terdapat 14 responden (70\%) yang bertindakan baik hal ini menyatakan bahwa peran tenaga kesehatan tidak berhubungan dengan perilaku/tindakan siswa/ Siswi karena diantara siswa/ Siswi yang mendapat peran tenaga kesehatan baiak masih ada siswa/ Siswi yang berperilaku kurang.

\section{Hubungan Pengetahuan Siswa/Siswi Tentang Pendidikan Seks Berdasarkan Peran Lingkungan (Teman Sebaya) dengan Tindakan Siswa/Siswi di SMA N 1 Doloksanggul Kecamatan Doloksanggul Kabupaten Humbang Hasundutan Tahun 2015.}

Berdasarkan uji chi-square, ada hubungan antara peran lingkungan (teman sebaya) dengan tindakan siswa/ Siswi di SMA N 1 Doloksanggul Kecamatan Doloksanggul Kabupaten Humbang Hasundutan Tahun 2015.

Menurut asumsi peneliti dalam penelitian ini hasil penelitian sesuai dengan teori dimana lingkungan (teman sebaya) memiliki hubungan dalam pembentukan tindakan remaja dimana hasil penelitian dari 100 responden yang diteliti 60 responden mendapat peran dari lingkungan (teman sebaya) baik dimana mayoritas 48 responden $(57,1 \%)$ bertindakan/ berperilaku baik. Dan terdapat 15 responden yang mendapat peran dari lingkungan (teman sebaya) cukup dimana 10 responden $(62,5 \%)$ bertindakan/ berperilaku baik. Dan terdapat 25 responden yang mendapat peran lingkungan (teman sebaya) kurang memiliki tindakan/ perilaku kurang sebanyak 25 responden (100).

\section{KESIMPULAN DAN SARAN}

\section{Kesimpulan}

Setelah dilakukan penelitian yang berjudul "Hubungan Pengetahuan Siswa/ siswi Kelas XI IPA Tentang Pendidikan Seks Dengan Tindakan Siswa/ siswi Di SMA N 1 Doloksanggul Kecamatan Doloksanggul Kabupaten Humbang Hasundutan Tahun 2015" dapat diambil kesimpulan sebagai berikut:

1. Tidak ada hubungan pengetahuan tentang pendidikan seks dengan tindakan siswa/ siswi di SMA N 1 Doloksanggul Kecamatan Doloksanggul Kabupaten Humbang Hasundutan Tahun 2015.

2. Ada hubungan jenis kelamin siswa/ siswi tentang pendidikan seks dengan tindakan siswa/ siswi di SMA N 1 Doloksanggul Kecamatan Doloksanggul Kabupaten Humbang Hasundutan Tahun 2015.

3. Tidak ada hubungan peran orangtua siswa/ siswi tentang pendidikan seks dengan tindakan siswa/ siswi di SMA N 1 Doloksanggul Kecamatan Doloksanggul Kabupaten Humbang Hasundutan Tahun 2015.

4. Ada hubungan peran guru siswa/ siswi tentang pendidikan seks dengan tindakan siswa/ siswi di SMA N 1 Doloksanggul Kecamatan 
Doloksanggul Kabupaten Humbang Hasundutan Tahun 2015.

5. Tidak ada hubungan media informasi tentang pendidikan seks dengan tindakan siswa/ siswi di SMA N 1 Doloksanggul Kecamatan Doloksanggul Kabupaten Humbang Hasundutan Tahun 2015.

6. Tidak ada hubungan peran tenaga kesehatan tentang pendidikan seks dengan tindakan siswa/ siswi di SMA N 1 Doloksanggul Kecamatan Doloksanggul Kabupaten Humbang Hasundutan Tahun 2015.

7. Ada hubungan peran lingkungan (teman sebaya) tentang pendidikan seks dengan tindakan siswa/ siswi di SMA N 1 Doloksanggul Kecamatan Doloksanggul Kabupaten Humbang Hasundutan Tahun 2015.

\section{Saran}

Berdasarkan penelitian yang didapat, peneliti dapat memberikan saran:

1. Diharapkan para guru SMA N 1 Doloksanggul dapat membina siswa/ siswi untuk memanfaatkan media informasi dengan benar, meningkatkan pengetahuan siswa/ siswi mengenai kesehatan reproduksi dan meningkatkan kegiatan ekstrakulikuler sehingga siswa/ siswi lebih banyak meluangkan waktu untuk hal-hal yang lebih bermanfaat.

2. Kepada institusi SMA N 1 Doloksanggul agar lebih meningkatkan pengembangan program kurikulum pendidikan seks dalam lingkup kesehatan reproduksi, konseling dan pelayanan kesehatan pada remaja serta perumusan kurikulum pendidikan pendidikan seks yang disesuaikan dengan tingkat pertumbuhan dan perkembangan remaja.

3. Kepada peneliti selanjutnya untuk mengembangkan penelitian ini dan menambahkan variabel-variabel yang sudah dicantumkan penulis.

4. Diharapkan kepada pemerintah untuk lebih mengadakan pengawasan/ pelarangan terhadap pemakaian internet khususnya dikalangan remaja.

5. Kepada para petugas internet hendaknya melarang anak sekolah berada di warung-warung internet selama jam sekolah dan mengawasi para remaja dalam pemakaian internet.

\section{DAFTAR PUSTAKA}

Adelima. 2012. Gambaran Pengetahuan dan Sikap Siswa / Siswi Kelas XI IPA 2 Tentang Pendidikan Seks. Jurnal Ilmiah Kesehatan Baru, I (01):46-65.

Arikunto, Suharsimi. 2010. Prosedur Penelitian Suatu Pendekatan Praktik. Jakarta. Rineka Cipta.

Budiarto, Eko. 2005. Biostatistika Untuk Kedokteran dan Kesehatan Masyarakat. Jakarta. EGC.
Devi, 2010. Persepsi Remaja Mengenai Pendidikan Seks di SMA Negeri 4 Magelang. Skripsi Fakultas Keguruan dan Ilmu Keguruan Universitas Sebelas Maret Surakarta. http: //etd. Eprints. Usms.ac.id/101168/3/f/100040200.pdf. diakses pada tanggal 31 Mei 2014.

Dianawati, Ajen. 2010.Pendidikan Skes Untuk Remja. Jakarta. Kawan Pustaka.

Hurlock, Elizabeth B. 2011. Psikologi Perkembangan Suatu Pendekatan Sepanjang Rentang Kehidupan. Jakarta. Erlangga.

Hidayat, A Aziz Alimul, 2011. Metode Penelitian Kebidanan \& Teknik Analisis Data. Jakarta. Salemba Medika.

http://www.ebookbrowsee.net/karya-tulis-ilmiah-tentangpendidikan-seks-untuk-remaja-pdf-d378513802/ diakses tanggal 15 Maret 2014 jam 09.09 WIB

http://mustikadewimustari.com/2013/02/contoh-karyatulis-ilmiah 21.html/ diakses tanggal 19 Maret 2014 jam 12.39 WIB.

http://www.referensimakalah.comV2013/03/pengertianpendidikan-seks. html/ diakses tanggal 22 Maret 2014 jam 09.43 WIB.

Irianto, Koes. 2013. Permasalahan Seksual. Bandung. Yrama Widya.

Listora. 2013. Analisis Faktor Yang Memengaruhi Perilaku Seksual Pada Remaja Sma Negeri Juhar Kabupaten Karo. Medan: Tesis FKM USU.

Nurdin, Adnil Edwin. 2011. Tumbuh Kembang Perilaku Manusia. Jakarta. EGC.

Notoatmodjo, Soekidjo. 2010. Metodologi Penelitian Kesehatan. Jakarta. Rineka Cipta.

Notoatmodjo, Soekidjo. Promosi Kesehatan dan Prilaku Kesehatan. Jakarta. Rineka Cipta.

Soekanto, Soerjono 2005. Sosiologi Suatu Pengantar. Jakarta. Raja Grafindo Persada.

Sugiyono. 2010. Metode Penelitian Kuantitatif Kualitatif dan $R \& D$. Bandung. Alfabeta.

Sunyoto, Danang. 2012. Biostatistik Untuk Kebidanan. Yogyakarta.Nuhamedika

Sarwono, Solita. 2007. Sosiologi Kesehatan. Yogyakarta. Gadjah Mada University Press.

Sarwono, W Sarlito. 2011. Psikologi Remaja. Jakarta. PT Rajagrafindo Persada.

Sarwono W Sarlito. 2011. Pengantar Psikologi Umum. Jakarta. PT. Rajagrafindo Persada. 